\title{
A Case-control Study of Vitamin A Level in Hydatidiform Mole
}

\author{
Andrijono*, Kukung Kurnia*, Nur Asikin**
}

\begin{abstract}
Abstrak
Mola hidatidosa merupakan kehamilan abnormal yang masih merupakan masalah dalam usaha meningkatkan derajat kesehatan reproduksi wanita, karena kejadiannya yang cukup tinggi serta karena komplikasi yang dapat ditimbulkan. Pencegahan dapat dilakukan bila faktor etiologi atau faktor risiko wanita penderita mola hidatidosa telah diketahui. Tujuan penelitian ini adalah untuk mengetahui faktor risiko tersebut yang diduga salah satunya adalah kadar vitamin A yang rendah. Penelitian ini merupakan kasus kontrol. Kasus adalah 30 orang penderita mola hidatidosa dengan kontrol adalah wanita hamil dengan padanan umur sela 4 tahun dan paritas sela 1. Dilakukan pengukuran kadar retinol darah puasa sesuai dengan cara Need dan Pearson. Kadar rata-rata retinol darah penderita mola hidatidosa adalah 10,52 $\mu \mathrm{g} / \mathrm{dl}$ sedangkan kadar tersebut pada kontrol adala h $12,89 \mu \mathrm{g} / \mathrm{dl}$. Kedua nilai tersebut berbeda bermakna secara siatistik. Risiko terjadinya mola hidatidosa pada wanita hamil berusia $\leq 24$ tahun dan menderita defisiensi berat vitamin A adalah 6,29 kali lebih tinggi dan pada wanita berusia $\leq 24$ tahun, berparitas nol dan menderita defisiensi berat vitamin $A$ adalah 7 kali lebih tinggi dibandingkan dengan kontrol.
\end{abstract}

\begin{abstract}
Hydatidiform mole is an abnormal pregnancy which constitutes a problem in the effort to improve the reproductive health level of women because of its high incidence rate and complications that may arise. Prevention may be perfomed if etiological factors or risk factors of the women with hydatidiform mole have been identified. The aim of this study was to identify those risk factors. One of the risk factor was suspected to be a vitamin A level. This study was a case control study. The cases were 30 patients with hydatidiform mole and the control were pregnant women of equivalent age of 4 years interval and parity interval of 1 . The measurement of fasting blood retinol level was done using Neeld and Pearson's method. The average level of blood retinol of the patients with hydatiform mole was $10,52 \mu \mathrm{g} / \mathrm{dl}$, and the average blood retinol of the control patients was $12,89 \mu \mathrm{g} / \mathrm{dl}$; statistically it was significantly different. The risk for the incidence of hydatidiform mole in the pregnant women of $\leq 24$ years of age with severe deficiency of vitamin $A$ was 6,29 times higher and the risk for hydatidiform mole in the women of $\leq 24$ years with nil parity and severe deficiency of vitamin $A$ was as many as 7 times higher than in control patients.
\end{abstract}

Keywords : Vitamin A, hydatiform mole

\section{INTRODUCTION}

Hydatidiform mole is one of the problems in women's reproductive health. This is because this disease is suffered mostly by women of young age and without children who still need their reproductive functions, and its incidence is high enough, i.e. one of 60 pregnancies or $16 \%,{ }^{1,2}$ One of the most dangerous

* Department of Obstetrics and Gynecology, Faculty of Medicine, University of Indonesia / Dr. Cipto Mangunkusumo General Hospital, Jakarta, Indonesia

** Department of Biochemistry, Faculty of Medicine, University of Indonesia, Jakarta, Indonesia hydatidiform mole complications is the occurrence of malignancy degeneration which results in the failure of reproductive functions, or even death. ${ }^{3,4}$

One of the efforts to promote women's reproductive health is through the prevention of the occurrence of hydatidiform mole by undertaking the studies on the etiology of this disease and its risk factors. The decrease of hydatidiform mole incidence will be a great significance in the efforts to promote women's reproductive health.

Hydatidiform mole is an abnormal pregnancy indicated by degeneration of hydropic chorionic villi, avascular chorionic villi and proliferation of trophoblast 
cells. ${ }^{5,6}$ The cause of these changes has not yet been identified. However, it has been understood that the changes in cell differentiation and cell proliferation are caused by the disorder of intracellular metabolism. One of the metabolism chains is the function of vitamin $A .{ }^{7,8,9}$ Therefore, it will be interesting to study whether there is a correlation between vitamin $\mathrm{A}$ and the incidence of hydatidiform mole. This study is performed with the purpose of attempting to give the tentative answer to that problem.

\section{MATERIALS AND METHODS}

The study was designed as a case control study. The cases were the patients with hydatidiform mole and the controls were the pregnant women. Two determining factors were age and parity. These two factors were used as matched parity with an interval of one and ages with interval of four. All the patients with hydatidiform mole which met the criteria of the study were included in the study, and these matched factors served as the control. The patients with hydatidiform mole included in this study were those evacuated at Dr. Cipto Mangunkusumo Hospital, neither receiving blood transfusion yet nor the treatment with vitamin $\mathrm{A}>5000 \mathrm{IU}$. The measurement of vitamin A performed was the level of fasting retinol, and it was carried out at the Laboratory Research Center for Immunoendocrinology Jakarta, according to Neeld and Pearson's method. ${ }^{10}$

\section{RESULTS}

During the period of a year study (June 1990-May 1991), a number of 30 cases of hydatidiform mole were qualified for the study.

The average cases were 25 years ( \pm SD: 5,73 ) with the youngest age being 18 years and the oldest 40 years. The average age of the control group was 26,43 years ( \pm SD: 4,28 ), the youngest age being 14 years and the oldest 38 years.

For parity, $70 \%$ of the cases and $76 \%$ of control group had parity of 1 or 0 , the rest had parity more than 1 . The average education length of case group was 7,96 years ( \pm SD: 3,64 ) while the control group being 10,7 years $( \pm$ SD: 3,78$)$. Statistically, all these factors did not differ significantly.

\section{The Level of vitamin A}

Table 1. The average level of vitamin $A$ in both groups

\begin{tabular}{llll}
\hline Group & $\mathrm{n}$ & $\overline{\mathrm{x}}$ & $\mathrm{SD}$ \\
\hline Mole & 30 & 10.52 & 3.94 \\
Result & 30 & 12.89 & 3.93 \\
\hline
\end{tabular}

$Z=2,33 \quad p<0,05$

The results of the study revealed a significant difference in vitamin A level between the case group of hydatidiform mole and the control group. The lowest vitamin A level found in the case group was $5,0 \mu \mathrm{g} / \mathrm{dl}$, the highest level was $17,5 \mu \mathrm{g} / \mathrm{dl}$, while the lowest vitamin $\mathrm{A}$ level in the control group was $6,7 \mu \mathrm{g} / \mathrm{dl}$, and the highest level was $21,8 \mu \mathrm{g} / \mathrm{dl}$.

These results showed a significant difference in vitamin A between the patients with hydatidiform mole and normal pregnant women.

Table 2. The average vitamin $A$ level according to age and group

\begin{tabular}{lrrrrrr}
\hline $\begin{array}{c}\text { Group } \\
\text { Age }\end{array}$ & \multicolumn{3}{c}{ n } & \multicolumn{1}{c}{ Case } & \multicolumn{3}{c}{ Control } \\
\hline-20 & 4 & 14,05 & 3,46 & 1 & 15,00 & 0,00 \\
$20-24$ & 11 & 9,37 & 3,64 & 12 & 3,30 & 3,51 \\
$25-29$ & 6 & 9,88 & 3,07 & 10 & 13,27 & 4,62 \\
$30-34$ & 5 & 12,04 & 5,11 & 5 & 11,02 & 4,40 \\
$35-39$ & 3 & 7,77 & 3,15 & 2 & 12,02 & 3,96 \\
$40-$ & 1 & 13,40 & 0,00 & - & - & - \\
\hline
\end{tabular}

$p>0,05 \quad p>0,05$

Table 3. The average vitamin A level according to parity and group

\begin{tabular}{crrcccc}
\hline Parity & & Case & & & Control & \\
& $\mathrm{n}$ & $\overline{\mathrm{x}}$ & SD & $\mathrm{n}$ & $\overline{\mathrm{x}}$ & $\mathrm{SD}$ \\
\hline 0 & 13 & 10,68 & 4,12 & 14 & 13,38 & 3,73 \\
1 & 8 & 10,30 & 2,26 & 8 & 12,14 & 3,35 \\
2 & 2 & 4,80 & 0,42 & 1 & 6,70 & 0,00 \\
3 & 1 & 11,60 & 0,00 & 1 & 12,10 & 0,00 \\
4 & 0 & - & - & 2 & 10,60 & 4,95 \\
$5+$ & & & & 4 & 15,57 & 5.08 \\
& 6 & 12,18 & 5.02 & & & \\
\hline
\end{tabular}

$p>0,05 \quad p>0,05$ 
Table 4. The average vitamin A level according to the level of education in both groups

\begin{tabular}{crrrrrr}
\hline $\begin{array}{c}\text { Education } \\
\text { (year) }\end{array}$ & $\mathrm{n}$ & $\begin{array}{c}\text { Case } \\
\overline{\mathrm{x}}\end{array}$ & $\mathrm{SD}$ & $\mathrm{n}$ & $\begin{array}{c}\text { Control } \\
\overline{\mathrm{x}}\end{array}$ & $\mathrm{SD}$ \\
\hline 0 & 1 & 13,40 & 0,00 & - & - & - \\
$1-6$ & 15 & 10,99 & 4,38 & 8 & 14,86 & 4,05 \\
$7-12$ & 13 & 9,24 & 2,95 & 20 & 11,88 & 3,68 \\
$12+$ & 1 & 17,10 & 0,00 & 2 & 15,20 & 3,54 \\
\hline
\end{tabular}

$p>0,05$

$$
p>0,05
$$

The results showed no influence of age, parity and education with regard to vitamin A level. These three factors in our study did not seem to affect the study on vitamin $\mathrm{A}$ in both the case group and the control group. Thus, these results differed from several studies which suggested that the above three factors play a role in affecting vitamin $\mathrm{A}$ level.

\section{Vitamin A deficiency}

The assessment of risks for the occurrence of hydatidiform mole in vitamin A deficiency showed OR $=2,51$.

Table 5. Distribution of cases and controls according to the presence or absence of vitamin A deficiency

\begin{tabular}{lccc}
\hline Group & Vit.A Def. (+) & Vit.A Def. (-) & Total \\
\hline Cases & 13 & 17 & 30 \\
Controls & 7 & 23 & 30 \\
\hline Total & 20 & 40 & 60 \\
\hline$p>0,05$ & & $O R=2,51$
\end{tabular}

Although there was no statistical difference, it was evident that the percentage of vitamin A deficiency in the patients with hydatidiform mole $(43,33 \%)$ was higher than that of control group $(23,33 \%)$. In the distribution of age and parity, the majority of age and parity in the cases of hydatidiform mole were the cases of less than 24 years of age, and parity of 1 . This finding was in according with the literature suggesting that the highest incidence of hydatidiform mole occurred in the yourig women with low parity. It will be of interest to study such tendency separately.

\section{Analysis of the women in the age group less than 24 years.}

Table 6. Vitamin A deficiency in the case and control group with age less than 24 years old

\begin{tabular}{lccc}
\hline Group & Vit. A Def. (+) & Vit. A Def. (-) & Total \\
\hline $\begin{array}{l}\text { Case } \\
\text { (mole) }\end{array}$ & 8 & 7 & 15 \\
$\begin{array}{l}\text { Control } \\
\text { (pregnant) }\end{array}$ & 2 & 11 & 13 \\
\hline
\end{tabular}

$p=0,038$

$$
O R=6,29
$$

These data suggest high risks, i.e. 6,29 times in the women group of $\leq 24$ years of age with vitamin A deficiency for developing hydatiform mole.

Table 7. Vitamin A deficiency in the case and control group with parity of 1 or less

\begin{tabular}{lccc}
\hline Group & Vit. A Def. (+) & Vit. A Def. (-) & Total \\
\hline $\begin{array}{l}\text { Case } \\
\text { (mole) }\end{array}$ & 9 & 12 & 21 \\
$\begin{array}{l}\text { Control } \\
\text { (pregnant) }\end{array}$ & 4 & 18 & 22 \\
\hline
\end{tabular}

$p>0,05 \quad O R=3,38$

On the other hand, analysis of the patients with parity of 1 showed no significant difference $(\mathrm{OR}=3,38)$. It will be of interest, therefore, to perform a separate study of the cases with nil parity.

Table 8. Vitamin A deficiency in the case and control group with nil parity and age less than 24 years old

\begin{tabular}{lccc}
\hline Group & Vit. A Def. (+) & Vit. A Def. (-) & Total \\
\hline Case & 7 & 6 & 13 \\
Control & 2 & 12 & 14 \\
\hline
\end{tabular}

$p<0,05 \quad O R=7$

It is obvious that there is a significant different between the case and control groups with nil parity, age less than 24 years old and vitamin A deficiency. The risk 
of hydatidiform mole in the women of less than 24 years with nil parity and suffering from vitamin A deficiency is 7 times higher than in the control group.

\section{Histologic Classification}

Several investigators did not find the influence of histologic classification on the likelihood of the posthydatidiform mole malignancy. However, this histologic classification did not provide a brief description of the essential changes in trophoblast cells that occurred, i.e. the more severe and the more numerous cases were classified as the more severe cases. Histologic classification of hydatidiform mole commonly referred to is the classification according to Hertig-Mansel. ${ }^{11}$

Table 9. The relationship between histopathologic classification and the average vitamin $A$ level

\begin{tabular}{crrr}
\hline $\begin{array}{c}\text { Histopathologic } \\
\text { classification }\end{array}$ & n & \multicolumn{1}{c}{ Vitamin A level } \\
\hline I & 6 & 13,12 & 4,68 \\
II & 20 & 9,90 & 3,32 \\
III & 4 & 9,70 & 5,11 \\
\hline
\end{tabular}

$F=1,7 \quad d f=2,27 \quad p>0,05$

Statistically, there was no significant difference between histologic level and vitamin A level. However, it was evident that the higher the histologic changes, the lower the vitamin A level.

\section{DISCUSSION}

One of the diagnostic parameters of hydatidiform mole is the presence of trophoblast cell proliferation. The direct cause of this proliferation is not known yet. The in vivo study showed that vitamin $A$ has the effect of inhibiting or controlling cell proliferation and enhancing cell differentiation. ${ }^{7,8.9}$ How vitamin A performs that role is unclear yet. Several mechanisms that may be affected include protein system of kinase $C$, cascade system, and several other biological effects, such as enzyme synthesis, genomic expression, extracellular effects, immunologic activity and protein kinase C cascade. ${ }^{12,13,14,15}$ It is of interest, therefore, to study whether vitamin A also plays a role against the proliferation of trophoblast cells.

Started by clinical study, i.e. control case study to identify the correlation of the occurrence of hydatidiform mole and vitamin A level, the analysis of vitamin A level showed that the majority of the cases and controls had vitamin A level below the normal $(20-40 \mu \mathrm{g} / \mathrm{dl})$. These results suggest that most pregnant women in the study suffered from vitamin A deficiency. This situation calls for special attention on the impacts it may have on pregnancy and how to deal with them. The level of vitamin A deficiency is mild if blood retinol level is $10-20 \mu \mathrm{g} / \mathrm{dl}$, and the deficiency is severe if the retinol level is $<10 \mu \mathrm{g} / \mathrm{dl}$. However, the average results of vitamin A level in the cases of hydatidiform mole and in the control group were statistically different. Analysis of age, parity, and education factors did not seem to show different result. Education factor is suspected to play a major role because there is a close correlation between education and socioeconomic conditions. Furthermore, the socioeconomic conditions play a major role in the quality of nutritional food. This correlation suggests a probable role of vitamin A deficiency in the incidence of hydatidiform mole.

One of the hypotheses explaining the occurrence of hydatidiform mole is the "blighted-ovum" theory. The genetic study revealed that the genotype of hydatidiform mole was of the father's gene, without the mother's. ${ }^{16}$ Thus, hydatidiform mole originates from fertilization without mothers factor, i.e. the ovum whose gene factor is not fertilized by the father's sperm. ${ }^{15}$ However, this situation still requires other factors because not all the blighted ovum develops into hydatidiform mole. This other factor is yet to be identified. And the factor that we attempted to study is vitamin A deficiency.

Epidemiological study of hydatidiform mole revealed that hydatidiform mole was generally developed by pregnant women of young age without children. This risk factor also constitutes the problem that is yet to be answered. It is of interest, therefore, to perform a study on the factors of young age, low parity or nil parity, and vitamin A deficiency. The interesting data of our study are the data of hydatidiform mole patients of $\leq 24$ years of age suffering from severe vitamin A deficiency. These data suggest a significant difference between the case and the control group. The risk for developing hydatidiform mole increases 6,29 times if the woman is under 24 years, pregnant, and suffering from severe vitamin A deficiency. 
Similarly, in the cases of $\leq 24$ years with nil parity, the data found revealed the risk of 7 times higher than in the control group. The magnitude of risk for the occurrence of hydatidiform mole by the accumulation of these factors underlines that the etiology of hydatidiform mole is multifactors.

Thus, the prevention for the occurrence of hydatidiform mole should be attempted through various aspects. Nevertheless, as it is a natural phenomenon that the first pregnancy occurs at young age, the risk factors that play a role, such as vitamin A deficiency. The severity of histologic changes can be seen from the compared data of histologic level and the average vitamin A level. The lower vitamin A level reflects the more severe histologic changes of hydatidiform mole cells.

Several studies of histologic levels of hydatiform mole revealed that this histologic level did not affect the risks for the occurrence of malignancy degeneration (Genest DR et al. personal communication). Thus, the results of this study are sufficient to show that the women of $\leq 24$ years with nil parity and suffering from severe vitamin A deficiency have the risk for developing hydatidiform mole seven times higher. Vitamin A level in the patients with hydatidiform mole compared with the pregnant woman control and histologic changes, which occurred more severely with the lower vitamin A level, suggest a strong likelihood of the role of vitamin A level deficiency in the occurrence of hydatidiform mole.

\section{CONCLUSION}

There is a significant difference of vitamin A level in the patients with hydatidiform mole and the control group. The risk for developing hydatiform mole in the women less than 24 years of age with nil parity and suffering from severe vitamin A deficiency is 7 times higher.

\section{REFERENCES}

1. Sastrawinata S. Permasalahan Penyakit Trophoblas. Seminar Sehari Penanggulangan Penyakit Trofoblas, Bandung, 1987

2. Martaadisoebrata D. Epidemiologi Penyakit Trophoblas di Indonesia. Simposium Sehari Neoplasma Trofoblas, Jakarta, 1984

3. Kashimura Y, Kashimura M, Sugimori H, Tsukamoto $M$. Prophylactic chemotherapy of hydatidiform mole. Cancer 1986; 58:624-9

4. Kim DS, Moon H, Kim KT, Moon YJ, Hwang YY. Effect of prophylactic chemotherapy for persistent trophoblastic disease in patients with complete hydatidiform mole. Obstet Gynecol 1986; 67:690-9

5. Lurain JR. Natural History Gestational Trophoblastic Disease. In: Szalman AE, Buchsbaum HJ, editors. Gestational Trophoblastic Disease. New York: Springer-Verlag, 1987: $3-8$

6. Tyrey L. Laboratory Methods for the Quantitation of Human Chorionic Gonadotropin. In: Szalman AE, Buchsbaum HJ, editors. Gestational Trophoblastic Disease. New York Springer-Verlag, 1987

7. Sporn M.B. Retinoids and Cancer: Introduction. Cancer Surveys $1983 ; 2: 221-2$

8. Goodman De Witt S. Vitamin A and retinoids. In: Health and disease. N Eng J Med 1984; 16:1023-31

9. Menkes MS, Comstock GW, Vuilleumier JP, Helsing KJ. Serum Beta Carotene, Vitamin A and E, Selenium, and the risk of Lung Cancer. N Eng J Med 1986; 13:1250-4

10. Neeld JB, Pearson WN. Macro and micro method for the determination of serum vitamin A using Trifluoroacetic acid. J Nutr 1963; 79:454

11. Hertig AT, Sheldon WH, Boston M. Hydatidiform mole. A pathological-clinical correlation of 200 cases. Am J Obstet Gynecol, 1947; 53:1-36

12. Schroder E, Rapaport E, Blackj PH. Retinoids and cell proliferation. Cancer Survey. 1983; 2:223-37

13. Bertram JS. Inhibition of neoplastic transformation in vitro by retinoids. Cancer Survey 1983; 2:238-53

14. Sporn MB, Roberts. AB. Retinoids in Differensiation and carcinogenesis, JNCI 1984; 73:1381-9

15. Muso Y, Moriwaki $\mathrm{H}$. Antitumor activity of vitamin A and its derivatives. JNCI 1984; 73:1384-93

16. Inchinoe K. Mechanism of Origin of Hydatidiform mole and Its ropensity to malignancy. In: Ichinoe $\mathrm{K}$, editor. Trophoblastic Disease. Tokyo: Igaku-Shoin 1986; 18-28 